\title{
TRANSCENDENDO O TEMPO E O ESPAÇO: INTERESTELAR, RELIGIÃO CIVIL NORTE-AMERICANA E A TORÇÃO DAS REGRAS DO GÊNERO DE FICÇÃO CIENTÍFICA
}

\section{Thais Farias Lassali ${ }^{1}$}

Resumo: A religiāo civil, conforme delineado por Robert Bellah (1976), diz respeito a uma ferramenta discursiva mobilizada na esfera pública estadunidense. Tal conceito se estabelece alegando que o campo político dos Estados Unidos tem uma dimensão religiosa essencial para o desenvolvimento, a mudança e manutenção da vida pública desse país. $\mathrm{O}$ presente artigo argumenta que esse aspecto também foi significativo para a conformação dos discursos de outros campos, tais como a indústria do entretenimento e, especificamente, Hollywood. É com esse intuito que as regras do gênero de ficção científica são dissecadas e, por contraste, o filme Interestelar (Interestellar, Nolan, 2014) é analisado, compreendido como um documento a partir do qual se pode entender a disseminação da religiáo civil por meio de filmes.

Palavras-chave: Interestelar; Religião civil; Filmes.

TRANSCENDING TIME AND SPACE: INTERESTELLAR, CIVIL RELIGION AND THE BEND OF THE GENRE OF SCIENCE FICTION

\begin{abstract}
As Robert Bellah (1976) stated, the civil religion is a discursive tool mobilized in north american public sphere. This concept concerns the politic field of United States as taken by a religious dimension to its country public life's development, change and maintenance. This article intent to support the point of view that the civil religion was relevant to the conformation of many others fields, such the entertainment industry and, specifically, Hollywood. With these purpose, the rules of the genre of science fiction will be dissected and Interestellar

1 Mestre em Antropologia Social pela Unicamp. Doutoranda do Programa de PósGraduação em Antropologia Social da Unicamp, Campinas, São Paulo, Brasil. E-mail: thaislassali@gmail.com.
\end{abstract}

Debates do NER, Porto Alegre, Ano i 9, N. 35, P. 347-368, Jan./Jul. 20 i 9 
(Nolan, 2014) will be analysed. It will be understood as a document from which one can comprehend the propagation of civil religion through movies.

Keywords: Interestellar; Civil religion; Movies.

\section{INTRODUÇÃO}

O presente artigo pretende relacionar a chamada religião civil norte-americana a uma parcela específica da produção hollywoodiana, a filmografia de ficção científica. O objetivo é argumentar que esse gênero cinematográfico possui uma íntima relação com a religião civil, sendo ela um de seus elementos narrativos mais centrais, pois está no cerne da relação que ele desenvolve com a tecnologia. Para tanto, primeiramente definirei o que é religião civil, compreendendo como essa ferramenta discursiva foi essencial para a autovisão pública dos Estados Unidos como nação. Em seguida, busco relacionar tal ferramenta com o cinema produzido no âmbito hollywoodiano, focalizando meu argumento em dois gêneros cinematográficos: o western e o filme de guerra para, então, adentrar a relação entre a religião civil e o gênero de maior interesse deste texto, a ficção científica.

Por fim, farei uma análise pormenorizada de Interestelar (Interstellar, Nolan, 2014), filme que tem como característica não seguir de maneira fiel às convençôes do estilo cinematográfico no qual majoritariamente se enquadra e, ao mesmo tempo, foi bastante criticado por especialistas e pelos espectadores por ser considerado "absurdamente sentimental” (Koh, 2016, p. 40). A película de Christopher Nolan permite-me desenvolver com mais facilidade um argumento que objetiva articular um imaginário ancestral norte-americano sobre seu lugar na geopolítica mundial, exatamente por ser considerado como destoante das produçóes do gênero e por tensionar fronteiras bem estabelecidas dentro desse estilo cinematográfico. Afinal, concordo com Mary Douglas que é justamente no contraste entre si e na 
ambiguidade disso decorrente que as estruturas e as convenções que regulam as relaçóes sociais se revelam com mais nitidez (Douglas, 2000).

Compartilho da ideia, desenvolvida por Talal Asad, de que as práticas e as enunciações religiosas "[...] devem ser explicados enquanto produtos de forças e disciplinas historicamente específicas” (Asad, 2010, p. 278). Isso significa dizer que, como diversos outros aspectos do mundo social, a religião civil norte-americana nutre uma íntima relação com as vicissitudes históricas, visto que ela se modifica e se transforma em confluência com as mudanças ocorridas nesse país ao longo dos últimos séculos. Dessa maneira, caberá também a este texto relacionar a ficção científica e, mais especificamente, o filme Interestelar, com uma breve análise do contexto político norte-americano em que esse mesmo imaginário se constitui e ajuda a constituir.

\section{A METÁFORA RELIGIOSA DE UMA SOCIEDADE MÍTICA}

Uma das grandes questões da modernidade europeia, nos séculos XVIII e XIX, foi lidar com os crescentes processos de racionalização e de fragmentação de esferas sociais anteriormente essenciais para o funcionamento e a autocompreensão daquelas sociedades. Um desses processos foi o de definir o lugar da religião, estabelecendo o privado como esse local, em oposição a um espaço público que se acreditava cada vez mais secularizado (Weber, 1982). Ou seja, o processo de diferenciação e de autonomização das esferas sociais na modernidade reposiciona a religiosidade na Europa, construindo um espaço público que se entende como democrático porque se encontra em oposição às questóes de foro particular, como a religião. Entretanto, esse é um processo contextual e, portanto, singular.

A formação nacional dos Estados Unidos, bem como a de sua democracia, passa por questôes e procedimentos diferentes: a própria formação da esfera pública estadunidense se dá em continuidade - e não em oposição - com a religiosidade (Randaxhe, 2003), ainda que se mantenha estipulado que a própria crença deva ser indiferente e mesmo ausente na administração 
pública. O país fora colonizado por europeus, principalmente ingleses, oriundos de um contexto pós-Reforma. Sem um Antigo Regime ou uma igreja de presença totalizante para se opor, como era o caso em relação à Igreja Católica em boa parte da Europa, surge uma imensa diversidade de denominaçóes protestantes (Marty, 1992).

Assim, trata-se de uma nação que já nasce pluralista e informada por religiôes que veem o campo político e religioso de maneira específica, entendendo o público como o lugar da comunidade e náo da impessoalidade, como na Europa. A Declaração de Independência dos Estados Unidos só vem confirmar essa tendência: nela existem quatro referências a deidade ligadas a uma ideia de ordem, lei e direito (Bellah, 1976, p. 175), fazendo referência ao Deus do Antigo Testamento. Ou seja, é notória a influência da cristandade nas relaçóes políticas, mas ela não se assume como exatamente cristá, justamente porque o próprio processo de constituiçáo de uma imaginaçáo nacional, nesse contexto, tem o pluralismo como pilar fundamental e como maneira específica de defender a liberdade religiosa.

Assim abrem-se as portas para a formação do conceito de religiáo civil estadunidense. $\mathrm{O}$ termo é introduzido no debate acadêmico dos Estados Unidos na década de 1960 com o artigo Civil Religion in America, de Robert Bellah. Segundo argumenta o autor, trata-se de um conjunto de crenças, símbolos e rituais que se utilizam de uma noção vaga de religiáo para dispor sobre um certo sentimento nacional e sobre a maneira como essa nação se compreende. Mais do que refletir sobre uma coesão cultural objetiva, a religião civil é "[...] um recurso de interpretaçấo cultural, uma ferramenta discursiva que conecta moralidade e política" (Coles, 2002, p. 1).

Ela se dispóe a partir de dois grandes marcos, que assumem caráter mítico/sagrado no decorrer da história norte-americana: a Independência, com a posterior escrita da Constituiçáa, e a Guerra Civil. Os escritos dos primeiros presidentes pós-Independência apresentam o senso de que existe um deus "[...] ativamente interessado e envolvido na história, com uma preocupaçáo especial pela América [sic]” (Bellah, 1976, p. 175). Ela se associa à ideia de terra prometida, em que se fundará "[...] uma ordem social 
nova e superior ou excepcional, que deverá ser a luz de todas as nações [...]" (Coles, 2002, p. 3) e ter como valores fundamentais a liberdade individual e religiosa, sendo "a nação escolhida".

Para essa concepção, a Guerra Civil e o assassinato de Abraham Lincoln adicionaram ares de Novo Testamento a essa particular historiografia norte-americana, trazendo à baila temas como morte e renascimento a esse conjunto narrativo de ampla circulação. O paralelo com Jesus Cristo é evidente: “[...] com um arquétipo cristão como pano de fundo, Lincoln, 'o presidente martirizado', foi ligado aos mortos na guerra, aqueles que 'deram a medida completa de devoçáo'. O tema do sacrifício foi indelevelmente inserido na religiáo civil [...]" (Bellah, 1976, p. 178), elevando a crença de que os Estados Unidos são um país resiliente que, independentemente do tamanho da privação ou do martírio, sairão fortalecidos das maiores dificuldades. Isso encontrou expressão simbólica no reiterado respeito pelos mortos das expediçóes militares norte-americanas, materializando-se ritualisticamente no Memorial Day, feriado surgido da Guerra Civil. Ao mesmo tempo, a figura de Lincoln, "[...] invoca aquele sentido de uma comunidade nacional, com sua metáfora bíblica de que 'uma casa dividida não pode se manter" (Ostendorf, 2001, p. 349).

A esses dois marcos, soma-se o sentimento missionário, bastante enraizado entre os protestantes, maioria no país desde seu surgimento. No caso específico da religião civil, esse princípio propagador relaciona-se com a expansão das fronteiras e as disputas para anexação de territórios no decorrer do século XIX. Nele está incluso o estabelecimento de uma sociedade que tem como valor fundamental a liberdade - desde que em seus próprios termos, importante pontuar -, a exaltação da capacidade de dominar o ambiente, independentemente do quão inóspito ele seja, e um tom civilizatório responsável pela dizimação de inúmeras etnias indígenas (Coles, 2002, p. 5).

Dessa maneira conformou-se, concomitante com a Independência e o desenvolvimento dos Estados Unidos como nação, a religião civil norte-americana. Ainda que o próprio conceito pareça abstrato, é possível 
reconhecer seu surgimento, como faz Bellah (1976), nos discursos dos primeiros presidentes. O mesmo autor analisa discursos do católico John F. Kennedy para demonstrar sua pertinência e manutenção na sociedade, expondo também sua centralidade no pensamento social norte-americano, bem como a profundidade histórica de sua perpetuação. Na realidade, vemos um mecanismo muito sofisticado de autoidentificaçáo nacional que está na base (até hoje) do estabelecimento de uma moralidade pública, regida por elementos compartilhados e reconhecidos por boa parte dos norte-americanos, por meio de um discurso vagamente religioso.

Nesse mesmo sentido é possível destacar a análise de Coles (2002) a respeito dos discursos de George Bush e Bill Clinton, mostrando como essa noção de uma religiosidade nacional é adaptável, a despeito dos posicionamentos desses ex-presidentes no espectro político norte-americano, ainda que possam haver nuances a depender da origem social e religiosa de quem invoca a noçáo, bem como do objetivo que se busca cumprir em sua mobilização. Afinal, como lembra Talal Asad, "[...] os símbolos religiosos [...] não podem ser compreendidos independentemente de suas relaçôes históricas com os símbolos não religiosos ou de suas articulaçôes no interior e sobre a vida social [...]" (Asad, 2010, p. 277), o que certamente se aplica para a religiáo civil estadunidense.

E o que tanto Bellah quanto Coles buscam apontar é como o campo político americano tem uma dimensão religiosa essencial para o desenvolvimento, mudança e manutenção da vida pública americana e, por que não, do American way of life. Meu argumento no presente texto é que esse aspecto também foi significativo para a conformação dos discursos de outros campos, dentre os quais destaco a indústria do entretenimento e, especificamente, Hollywood. 


\section{ESCREVENDO A RELIGIÃO CIVIL PELO CINEMA}

Algo a se notar é que Hollywood, desde seu surgimento, “[...] não desenvolveu uma dimensão religiosa independente daquela da vida norte -americana, mas em diálogo e em negociação com ela” (Jozajtis, 2002), a partir do uso e caracterização dos personagens, do desenvolvimento da narrativa, dos estereótipos e do uso dos cenários e da cinematografia. Mesmo em relação ao estabelecimento de Hollywood como um polo massivo de produção cinematográfica, é notória a ideia de que se tratou de um meio importante de difusão do modo de vida estadunidense, principalmente na Segunda Guerra Mundial e na Guerra Fria, fazendo com que a indústria assumisse, de certa maneira, um modo missionário de se colocar em relação à religiâo civil. Em outras palavras, “[...] os sonhos ideológicos e a experiência histórica que inspirou o excepcionalismo Americano [sic] também impulsionaram sua cultura popular e comercial" (Ostendorf, 2001, p. 340).

Dentre os inúmeros gêneros cinematográficos oriundos da indústria, três destacam-se por sua relação mais evidente com a religião civil: o western, o filme de guerra e a ficção científica. O primeiro, conhecido em português como faroeste ou bang bang, tem sua era de ouro entre as décadas de 1930 e 1960 e, segundo a definição do American Film Institute, trata-se de “[...] filmes que se passam no Oeste Americano que corporificam o espírito, a luta e o legado da nova fronteira" (American Film Institute, 2010). Essa definição por si só já é bastante representativa da religião civil, mas a isso soma-se a maneira como esse gênero constrói seu cenário típico, as planícies áridas do deserto. Elas assumem o papel de uma paisagem moralizante, moldando o comportamento e o caráter das pessoas, enfatizando a dureza do meio ambiente e necessidade de controlá-lo e superá-lo. Em contraste a isso, é bastante frequente que a ação ocorra em decorrência da presença da técnica, imprescindível para a domesticação da natureza, objetivada nos enredos dos filmes de faroeste na forma de estradas de ferro, da locomotiva ou de linhas de telégrafo, que comumente representam a chegada da civilização. 
Essa mesma contraposição também aparece nos westerns, nos embates entre brancos e indígenas, sendo os últimos ora aproximados do polo da selvageria e da violência, seres que acabam por impedir o processo de crescimento da nação, ora mostrados como recém-civilizados, portanto, docilizados. O que se coloca em jogo aqui é a visão sobre os colonizadores, que, em contraposição com um ideal selvagem, seja do ambiente, seja dos povos indígenas, assumem características heroicas relacionadas à dureza $\mathrm{e}$ à resiliência. Essa é uma maneira não religiosa de expressar um imaginário associado à religiáo civil, compreender os cowboys como missionários responsáveis por levar a palavra da civilização, da nação e de seus ideais para os mais distantes rincôes da naçáo que, ao final, estava sendo formada justamente por esses esforços.

Já o filme de guerra ganha popularidade no decorrer da Segunda Guerra Mundial, e pode ter como contexto histórico os principais confrontos do país no ao longo do século XX, desde as duas Grandes Guerras até as Guerras do Vietnă, chegando também a conflitos contemporâneos como aqueles ocorridos no Iraque e no Afeganistáo. Belton (1994) define esse gênero cinematográfico, além da presença do conflito armado, pela suspensão da moralidade civil e primazia dos objetivos coletivos em detrimento das motivaçóes individuais. Assim, torna-se evidente o modo pelo qual o filme de guerra dialoga com a religiáo civil: por meio da devoção aos princípios de liberdade dos Estados Unidos, que faz com que as pessoas arrisquem suas vidas e não temam a morte em nome do dever de fazer as convicçôes nacionais perdurarem e se expandirem. Ou seja, está implícito nele o sacrifício como um valor inestimável, por meio do qual se pode alcançar novos patamares ou escrever eternamente seu nome na história.

\section{RELIGIÃO CIENTÍFICA, FICÇÃO CIVIL}

Dos estilos cinematográficos aqui tratados, muito provavelmente a ficçáo científica seja aquele em que as características da religiáo civil são 
encontradas de maneira mais metafórica. Estão presentes em seus filmes tanto a visão missionária, a ideia de um povo escolhido e os ideais de sacrifício, mas não de maneira tão manifesta quanto no western e no filme de guerra. Isso porque trata-se de um gênero de difícil circunscrição, que tem elementos estilísticos bastante variáveis. Exatamente por essa dificuldade, a literatura especializada toma como ponto central para a definição do mesmo uma relação narrativa entre os termos ciência e tecnologia, humano e desconhecido. Assim, a ficção científica encena as possibilidades sociais da ciência e da tecnologia (Sobchack, 2005, p. 262), fazendo-as interagir, "[...] com um menos enfatizado, mas ainda presente, transcendentalismo [...] tentando conciliar o humano com o desconhecido" (Sobchack, 1980, p. 63).

É a partir desse desconhecido, e de sua relação com a ciência e a tecnologia, que se pode vislumbrar a maneira pela qual a ficção científica norte-americana relaciona-se com a religião civil desse mesmo país. É possível dizer que, de uma maneira geral, o sci-fi entende que a ciência é uma ferramenta essencial para a compreensão de facetas ainda não exploradas da vida e da existência humanas. Ao mesmo tempo, ele estabelece um limite para o conhecimento humano: assuntos como a imortalidade ou a capacidade de criar vida por meios não sexuais são considerados de uma esfera sobre-humana. Quando ultrapassa-se essa divisa, via de regra, criam-se problemas. É inegável que existe aí uma noção de deidade que, justamente como na religião civil, é vaga. Muitos filmes falam do desconhecido como um âmbito divino, inclusive fazendo menção direta a Deus, mesmo que em termos genéricos.

Estabelecidos os limites da competência e da sabedoria humanas, existe apenas um tipo de personagem capaz de vagar pelo desconhecido de maneira aceitável: aquele que tem capacidades heroicas. O herói de ficção científica é representado como o paradigma de humanidade da narrativa, é nele que se encontram características necessárias para se realizar um ato capaz de salvar toda a humanidade. Ainda assim, ele é uma pessoa comum, que não se destaca por nenhuma excepcionalidade além da racionalidade, da sagacidade e da coragem, sendo muitas vezes tornado herói pela necessidade das circunstâncias. Ele tem a capacidade de ultrapassar a fronteira do que não 
se conhece, porque o seu objetivo é benevolente e desinteressado, estando disposto a se sacrificar por um bem maior.

A semelhança com a história de Jesus é inegável, mas arrisco dizer que o herói de ficção científica aspira mais a emular uma estrutura narrativa que remete à figura de Lincoln do que ao filho do Deus do catolicismo. Isso porque, ainda que o personagem principal do referido gênero cinematográfico seja genérico, características como a racionalidade são mais próximas do mito do primeiro do que do segundo. Por outro lado, ainda que os filmes de ficção científica se coloquem como totalizantes, mostrando um tipo de conflito ou problema que parece abarcar toda a humanidade como espécie, ainda assim, eles se passam nos Estados Unidos - o que parece fazer toda a diferença, como argumentarei. As invasões alienígenas, os super-robôs malignos, ou seja lá o que for, ameaçam categorias essenciais para a autocompreensão nacional desse país, como a liberdade e a individualidade. E a maneira pela qual esses conflitos são resolvidos envolvem valores e um imaginário que, como demonstrei, geralmente são associados à ideia de religião civil, via de regra passando pelo reestabelecimento ou pela reformulação da comunidade porque “[...] uma casa dividida não pode se manter". A crítica da revista Time diz que se trata de "[...] um filme épico sobre a história e o futuro da humanidade" (Agel, 1970), o Los Angeles Times chama de "realização impressionante do futuro espacial [...] um marco histórico, um ponto de referência para um marco espacial, na forma de arte cinematográfica [...]" (Agel, 1970), enquanto o crítico Phillip French relaciona Kubrick com G. W. Griffith (Agel, 1970). As críticas negativas muito correntemente destacam a "falta de criatividade" de Kubrick em mostrar algo que já estava nos televisores de inúmeras casas norte-americanas. Aquilo não poderia ser cinema, porque já era realidade.

O herói parece ter a razão e o destemor como características mais por ser estadunidense do que por ser propriamente heroico. Afinal, como todas as categorias sociais, o heroísmo é também contextual. Segundo a autoconsideração nacional, foram esses os atributos que levaram os peregrinos a chegarem no país, que fizeram com que esse deixasse de ser uma colônia 
e, principalmente, que o permitiram alçar as proporçóes continentais que tem hoje. É outra característica fundante desse personagem típico da ficção científica o fato dele tornar-se herói pela necessidade, recebendo um chamado à aventura. Trocando em miúdos, significa ser escolhido para realizar uma tarefa hercúlea, exatamente como Bellah (1976) identifica nos discursos dos primeiros presidentes. A cereja do bolo: o herói só pode ser selecionado para sua missão porque é capaz de se sacrificar por um bem maior - idealmente a humanidade, na prática, a naçáo e seus valores.

Abstrato? Com certeza, mas com um exemplo tudo se elucida. Em 2001: uma odisseia no espaço (2001: a space odyssey, Kubrick, 1968), vemos a evolução da raça humana, desde o macaco, a partir do domínio da técnica, que tem como ignição o surgimento de um imenso monólito preto. Essa figura misteriosa surge na obra em todos os momentos em que a humanidade dá um salto tecnológico, que é acompanhado também de uma mudança na própria natureza humana: de um animal indefeso para alguém que usa ossos como armas e descobre a capacidade de matar um semelhante; daqueles que sabem fazer satélites e que chegaram à Lua para aqueles que podem desbravar mais ainda o espaço e enviar uma missão tripulada para Júpiter; daqueles que são subjugados por suas próprias invenções (no caso, pelo computador HAL, que assassina quase toda a tripulação da nave Discovery), para aqueles que conseguem transcender a própria humanidade (Lassali, 2015).

Não se sabe exatamente que figura desconhecida colocou os tais monólitos no caminho da humanidade, mas o filme sugere que, quem quer que tenha feito isso, fez por vontade própria e, mais do que isso, porque tem capacidades sobre-humanas e deliberadamente investiu na evolução da espécie. Segundo o próprio Stanley Kubrick, “[...] o enredo simboliza a busca por Deus [...]” (Bailey, 1972 apud IMDB, 2014), mas como uma ideia transcendente e não como uma concepção necessariamente ligada a alguma religião. Assim, na narrativa, o uso que os humanos fazem da tecnologia, como armas e como meio de criar criaturas superinteligentes, acabam, no decorrer dos milênios, por desumanizá-los. 
Essa busca realiza-se com a chegada de Dave Bowman, único sobrevivente da Discovery, em Júpiter. Isso após ter de descontinuar um supercomputador, tido no filme como a maior inteligência artificial já feita. Novamente nas palavras de Kubrick, Bowman é um herói “[...] indo de alguma maneira no submundo, ou no sobre-mundo, e encontrando perigos e experiências assustadoras. Então, ele re-emerge [...] em uma forma humana altamente melhorada” (Kloman, 1968). Ainda que Bowman não seja exatamente o herói prototípico descrito anteriormente e que o filme permita diversas leituras, as mais filosóficas possíveis, se considerarmos o contexto histórico de sua produção, 2001: uma odisseia no espaço ganha um caráter magnífico, altamente relacionado com a corrida espacial e, por consequência, com a religião civil da época.

A melhor maneira de refletir sobre essas questóes é a partir da análise a respeito da recepçáo da película. A crítica da revista Time diz que se trata de "[...] um filme épico sobre a história e o futuro da humanidade [...]" (Agel, 1970); o Los Angeles Times chama de "realização impressionante do futuro espacial [...] um marco histórico, um ponto de referência para um marco espacial, na forma de arte cinematográfica” (Agel, 1970), enquanto o crítico Phillip French relaciona Kubrick com G. W. Griffith (Agel, 1970). As críticas negativas muito correntemente destacam a "falta de criatividade" de Kubrick em mostrar algo que já estava nos televisores de inúmeras casas norte-americanas (Agel, 1970). Aquilo não poderia ser cinema porque já era realidade.

\section{TORCENDO AS REGRAS DO GÊNERO PELA RELIGIÃO}

Até o presente momento do texto, demonstrei que a religiáo civil, apoiando-me em Coles e Bellah, é um recurso narrativo mobilizado na esfera pública dos Estados Unidos como um conjunto de crenças que dita a visão e a estima desse país sobre si mesmo. Sendo um discurso aparentemente compartilhado pelos estadunidenses, ele pode encontrar ressonância nos 
mais diferentes campos da sociedade, o cinema incluso. Em Hollywood, a religião civil encontrou anteparo em diversos gêneros cinematográficos, como o western, o filme de guerra e a ficção científica.

Nessa última, entretanto, ela surge de maneira mais cifrada. Trata-se de um estilo baseado na relação entre a ciência e o desconhecido, tendo como mediador disso a ideia de humanidade, que se materializa principalmente na figura do herói. É por meio desse personagem que a religião civil encontra seu lugar no estilo de ficção científica, ela professa duas ideias principais: primeiramente, a de que os norte-americanos são excepcionais de tal maneira que foram escolhidos para a grandeza e, relacionado a isso, a de que, para alcançar essa grandiosidade são necessários sacrifícios, jogando principalmente com a figura do ex-presidente Abraham Lincoln. Isso realiza-se na figura do herói de tal maneira: ele é aquela figura que, por suas características benevolentes, é escolhido para uma aventura grandiosa tal que possibilitará a salvação de toda humanidade. Ao mesmo tempo, para realizar tal feito, ele precisa se sacrificar, ainda que metaforicamente.

Tendo isso em vista, o caso de Interestelar é peculiar. Por um lado, o filme canaliza com bastante força a religiáo civil, tendo como personagem principal um astronauta da NASA absolutamente fiel a esse conjunto de princípios civis. Por outro, a resolução da narrativa encontrada pelo diretor Christopher Nolan não agradou parte dos críticos e da audiência. Muitos dizem que se trata de um "furo" na história, um Deus ex machina, um final preguiçoso e plano. Minha suposição em relação a esse "problema" visto pelas pessoas em Interestelar é compartilhada por James Koh: "[...] o encerramento desobedece as regras do gênero de ficção científica, que demanda que o protagonista use a sagacidade, a lógica e a razão [...]" (Koh, 2016, p. 40), algo que não ocorre na película de Nolan.

Segundo o IMDB, o filme pode ser resumido da seguinte maneira:

O futuro da terra é desafiado por desastres, pela fome e pela seca. Existe apenas uma maneira de garantir a sobrevivência da humanidade: uma viagem interestelar. Um buraco de minhoca recém descoberto nos confins distantes 
do nosso sistema solar permite a um time de astronautas ir onde nenhuma pessoa jamais esteve, procurar por um planeta que possa ter um meio ambiente capaz de sustentar a vida humana. (Interestellar, Nolan, 2014)

No futuro distópico de Insterestelar, em que o meio ambiente do planeta Terra entrou em colapso, tornando-se progressivamente infértil, a única atividade econômica considerada socialmente relevante é a agricultura. É a partir desse contexto que conhecemos Joseph Cooper, engenheiro e ex-piloto da NASA que, por força das circunstâncias, viu-se obrigado a assumir a ocupação de fazendeiro. Essa situação contrasta-se com o fato dele ter feito parte de uma instituição que tem muito arraigada em si a crença no valor do conhecimento técnico relacionado às visões sobre a importância da ciência. Assim, a vida na terra torna-se desesperadora para ele.

É do personagem a frase: “[...] nós estávamos acostumados a olhar para o céu e sonhar com nosso lugar nas estrelas, agora nós apenas olhamos para baixo e nos preocupamos com nosso lugar na sujeira" (Interestellar, Nolan, 2014). A resposta que Cooper ouve, algo que o filme tenta estabelecer durante toda sua primeira parte, é que ele é um homem fora de seu tempo, porque a época de prosperidade que permitia à "humanidade" (aos americanos) olhar para estrelas já passou. O que resta é conviver com as tempestades de poeira e torcer para que as plantaçóes não pereçam, tornando latente a "[...] perda coletiva de esperança e do espírito pioneiro que acredita em sua capacidade de mudança” (Sobchack, 2014, p. 23). Nolan constrói um futuro em que aquele que carrega em si a religião civil americana é considerado, pelos outros personagens, um deslocado.

Ao mesmo tempo, as tempestades de detritos fazem com que tudo esteja sempre surrado, empoeirado e encardido, e como bem nos lembra Mary Douglas, "[...] onde há sujeira há sistema” (Douglas, 2000, p. 50). O fato da imundície incomodar não apenas as pessoas ficcionais, mas também aquelas que as assistem, salienta exatamente que Cooper está certo em ainda professar a religião civil, errados estão aqueles que perderam a esperança e aceitaram uma condição de vida absurda. Ou seja, o caráter distópico do 
filme na realidade parece mais ressaltar a perda da convicção na civilidade norte-americana do que de fato comentar sobre a situação do planeta. É exatamente em situaçôes imaginadas como essa que se costuma afirmar, conforme a crença da religião civil, que os cidadãos dos Estados Unidos se levantam e agem. Por isso, não é aleatório que a NASA ainda exista, mesmo que, no filme, estivesse como que escondida, como seus antigos funcionários (e ideólogos), tendo que viver nos subterrâneos, porque, como diz o personagem de Michael Caine, professor Brand, “[...] não aceitam mais que se gaste tanto em algo que não seja comida” (Interestellar, Nolan, 2014).

Assim, a um primeiro olhar, Cooper parece um exemplo clássico de um herói de ficção científica. Entretanto, o desenrolar do filme termina por negar essa impressão: o personagem que de fato usa "a sagacidade, a lógica e a razão" para resolver, a narrativa é sua filha, Murph. A conhecemos ainda criança, sendo assombrada por algo que no filme recebe o nome de "fantasma", uma força desconhecida que derruba os livros da estante da garota. Ao invés de se assustar, a menina, como uma aspirante a cientista, reúne dados e percebe que a tal entidade está tentando se comunicar. Em dada cena, o pai é chamado na escola para ouvir da professora que ela havia levado um livro sobre aterrissagens lunares, explicando aos colegas sobre o que havia aprendido nele.

[Cooper] - Você não acredita que nós chegamos à Lua?

[Professora] - Eu acredito que foi uma peça de propaganda brilhante [...] e se nós não quisermos repetir os excessos e desperdícios do século $\mathrm{XX}$, temos que ensinar nossas crianças sobre esse planeta, não fábulas de deixá-lo. (Interestellar, Nolan, 2014)

Assim, fica estabelecido que Murph, como o pai, tem em si os princípios da religião civil, o que estou considerando aqui, baseada na literatura especializada sobre o tema aplicada ao universo cinematográfico, como algo que tem se revelado fundamental para a constituição dessa mesma imaginação nacional. Ela não é daqueles que olha para baixo, mas para cima. 
Pai e filha descobrem juntos a existência da missão Lazarus, da agência espacial norte-americana, que pretendia "reviver" a humanidade enviando exploradores para um sistema de planetas que aparentavam possuir características que permitiam a vida humana e pudessem ser colonizados. Para o desespero da garota, que se sente traída, Cooper aceita fazer parte da delegação que deve viajar para um buraco de minhoca aberto próximo a Saturno para acessar tais planetas desconhecidos e coletar dados para descobrir se a Lazarus obteve resultados. Assim, o filme ganha dois fios narrativos que ocorrem em velocidades temporais diferentes: o da nave Endurance, que leva Cooper e seus companheiros para a viagem interestelar que pode ajudar a salvar a vida terráquea; e o da Terra, com Murph lidando com a partida do pai e, com a passagem acelerada do tempo, tornando-se uma cientista da NASA cujo trabalho busca uma solução para a equação da gravidade. É esse conjunto de números e teoremas matemáticos que permitirá a saída dos humanos do planeta e, portanto, sua salvação.

Essas linhas temporais são muito imbricadas entre si, porque enquanto a garota investiga soluções para os humanos, ela pensa também em seu pai, ao passo que o que o levou para o espaço, além da crença em um futuro melhor, foi também a vontade de dar para sua família uma vida diferente daquela em meio à sujeira.

Em contraste com a maioria dos filmes de ficção científica, os dramas pessoais dos personagens principais não funcionam para meramente humanizá-los - e prover um ocasional alívio da ênfase do gênero na exposiçẫo científica [...]. Ambos os fios narrativos, íntimo e cósmico, são essenciais um para outro (Sobchack, 2014, p. 22).

Então, o momento em que Cooper se joga no buraco negro Gargantua, pensando em voltar para o Sistema Solar para salvar seus filhos, é mostrado, utilizando recursos de montagem cinematográfica, em conjunto com o momento em que Murph chega mais perto da resposta que solucionará o problema da Terra. A entrada dela no seu antigo quarto, aquele com o tal 
"fantasma", corresponde à entrada de seu pai em um aglomerado multidimensional construído por seres superiores.

Essas figuras são, desde o início do filme, referidas apenas como "They" (Eles). Foi vontade deles a criaçáo do buraco de minhoca que permitiu com que a missão Lazarus alcançasse planetas possivelmente habitáveis. São eles também que parecem, desde o começo, controlar a falha gravitacional que faz com que os livros da estante de Murph, naquele mesmo quarto aparentemente assombrado, caiam. Aqui, os ecos com 2001: uma odisseia no espaço e a ideia de uma força superior guiando os caminhos humanos pelo espaço são evidentes, mas o caminho tomado por Nolan difere bastante daquele de Kubrick.

Ao entrar no aglomerado, em companhia do computador TARS, Cooper percebe algo fundamental para a trama:

[TARS] - Eles não nos trouxeram aqui para mudar o passado.

[COOPER] - Mas Eles não nos trouxeram aqui! Nós nos trouxemos! [...] Você não percebe, TARS? Eu me trouxe aqui! Nós estamos aqui para nos comunicarmos com o mundo tridimensional. Nós somos a ponte. Eu pensei que eles haviam me escolhido, mas eles escolheram ela!

[TARS] - Mas por que, Cooper?

[COOPER] - Para salvar o mundo! Tudo isso sáo todos os momentos do quarto de uma pequena garota. É infinitamente complexo. Eles tem acesso ao tempo e ao espaço infinitos, mas Eles náo tem ideia dos limites. Eles náo conseguem achar um espaço específico no tempo, Eles não conseguem se comunicar, é por isso que eu estou aqui. Eu vou achar um jeito de falar com a Murph, assim como eu encontrei esse momento.

[TARS] Mas como, Cooper?

[COOPER] Amor, TARS, amor! [...] Minha conexão com Murph é quantificável, é a chave! (Interestellar, Nolan, 2014)

É justamente esse o ponto de virada da narrativa que afasta Interestelar das convençôes da ficção científica. O uso "comunicativo" do buraco e da 
gravidade faz sentido dentro da maneira que o filme estabelece a física, assim como a sobrevivência dentro de um buraco negro, especialmente com a "sala" criada por Eles. O que é inaceitável, de uma perspectiva das regras daquele gênero cinematográfico, é o amor ser parte central da resolução do problema do filme. É justamente esse apelo aos sentimentos em um problema científico que é considerado pelos críticos como "um furo" da narrativa (Koh, 2016).

O papel de Cooper não foi usar a inteligência ou a racionalidade, mas encontrar um meio de comunicação com sua filha, o amor. Em dado momento do filme, ele é definido por uma cientista, interpretada por Anne Hathaway, como “[...] a única coisa que nós somos capaz de perceber que transcende dimensóes de tempo e espaço" (Interestellar, Nolan, 2014). Assim, o pai de Murph:

[...] é recompensado por sua resiliência moral. Ele sacrifica tudo que ele tem para salvar sua filha, e mesmo depois que ela perde a fé nele, guardando rancor, ele ainda mergulha na Gargantua para salvá-la. [...] A narrativa recompensa o heroísmo de Coop porque ele é essencialmente uma figura como Jesus (Koh, 2016, p. 45).

Ou seja, justamente aquele que transmite a mensagem de seres superiores por meio do amor.

Assim, aquele que deveria salvar a humanidade em termos da religião civil, que durante a maior parte de Interestelar, apresenta-se como o herói de ficção científica, realiza sua função em termos religiosos que remetem a imaginários especificamente cristãos. Quem passa inobservada na película é a personagem que realmente mobiliza a sagacidade e a lógica para resolver definitivamente a narrativa. A verdadeira heroína de ficção científica da obra de Nolan é Murph. É ela quem resolve a equação da gravidade e, de fato, auxilia os humanos a saírem daquele planeta inóspito e empoeirado. Ela canaliza muito mais os ideais ao redor da figura histórica de Lincoln. O estranhamento causado na audiência advém do pouco tempo de tela dado ao desenvolvimento da personagem como uma heroína que mobilize os ideais relacionados ao ex-presidente estadunidense. 
Assim, Interestelar apresenta uma maneira inovadora de lidar com a religião civil na ficção científica. Ela está presente, ela é de suma importância, mas seu papel na resolução da narrativa é deslocado. Aquele que em todo o decorrer do filme aparece como seu grande representante, Cooper, burla as expectativas, passando o bastão para que outra personagem, Murph, conduza as qualidades civis norte-americanas à sua fruição esperada.

Os temas tratados no filme de Christopher Nolan ecoam não apenas a religião civil de uma maneira geral, mas também aquela formatada especificamente por Barack Obama, o último presidente democrata norte-americano, que cumpriu dois mandatos, encerrados no final de 2016. Em seu discurso sobre o financiamento de quarenta milhóes de dólares para a NASA, o então presidente dos Estados Unidos disse algo que poderia ter sido dito por Cooper ou Murph: “[...] o programa espacial sempre capturou uma parte essencial do que significa ser norte-americano - alcançar novos auges, ir além do que antes parecia ser impossível” (Obama, 2012). Da mesma maneira, dois temas centrais de Interestelar foram a tônica de diversos discursos dele, principalmente em campanha: o amor e a esperança.

Essa última mostrou-se absolutamente presente desde o começo da primeira campanha de Obama. A possibilidade de encontrar alguém que lidasse com a profunda crise econômica que se aproximava, assim como eleger o primeiro representante nacional negro, encontrou corpo justamente no uso reiterado da palavra esperança. Concomitantemente, na boca do presidente, a palavra amor, como na película, aparece muito ligada à família. São incontáveis as vezes em que ele anunciou publicamente seu amor por sua esposa, Michelle, e suas filhas, Sasha e Malia. Também não é raro encontrar falas do ex-presidente associando esse sentimento com a nação e a liberdade. Por exemplo, ao aceitar concorrer à reeleição, em 2012, Obama proferiu, para todos presentes na Convenção do Partido Democrata: “[...] [reconhecemos] que uma liberdade sem comprometimento com os outros, sem amor, sem caridade ou sem patriotismo, não é digna dos nossos ideais fundantes, e daqueles que morreram em seu nome". 
Em discurso após a confirmação de sua segunda vitória, ele apresenta uma nova versão dessa ideia, mais contundente, por falar para todo o país e ter, justamente, um teor conciliatório findada a disputa política ressaltada nos meses que antecedem as eleiçóes, mas com a mesma tônica:

[...] esse país funciona apenas quando nós aceitamos certas obrigaçôes, uns com os outros e com as futuras gerações, porque a liberdade pela qual tantos norte-americanos lutaram e morreram traz consigo responsabilidades [...], dentre as quais o amor, a caridade, o dever e o patriotismo. É isso que faz os Estados Unidos grandioso. (Obama, 2012)

Assim, Obama parece articular algo que também está presente em filmes como o de Nolan, aqui analisado brevemente. Qual seja, a ideia de que o amor é algo que une as pessoas, que faz com que elas criem laços profundos. $\mathrm{O}$ discurso do primeiro e o filme do segundo são duas maneiras de apresentar a maneira como pode estar sendo compreendida a religião civil estadunidense no período retratado. Assim, parece-se reatualizar um imaginário extremamente poderoso sobre a constituição dos Estados Unidos como nação, que, como pretendi demonstrar, perpassa não apenas o discurso público de figuras políticas como também a produção cultural desse país.

\section{REFERÊNCIAS}

AGEL, Jerome. The Making of Kubrick's 2001. New York: New American Library, 1970.

AMERICAN FILM INSTITUTE. America’s 10 Greatest Films in 10 Classic Genres. 2010. Disponível em: http://www.afi.com/10top10/. Acesso em: 11 jun. 2018.

ASAD, Talal. A construção da religião como uma categoria antropológica. Cadernos de Campo, n. 19, p. 163-184, 2010. 
BANHAM, Reyner. Los Angeles: a arquitetura de quatro ecologias. São Paulo: Martins Fontes, 2013.

BELLAH, Robert. Civil Religion in America. Beyond belief - Essays on religion in a post-traditional world. New York: Harper \& Row Publishers, 1976. BELTON, John. American cinema/American culture. New York: McGrawHill, 2009.

COLES, Roberta. Manifest Destiny Adapted for 1990's War Discourse: Mission and Destiny Intertwined. Sociology of Religion, v. 63, n. 4, p. 403-426, 2002. DAVIS, Mike. Ecologia do medo. Rio de Janeiro: Record, 2001.

DOUGLAS, Mary. Pureza e Perigo. São Paulo: Perspectiva, 2000.

IMDB. Interstellar. 2014. Disponível em: https:/www.imdb.com/title/ tt0816692/. Acesso em: 13 jun. 2018.

JOZAJTIS, Kris. American Civil Religion, The Lost Cause, and D.W. Griffith: The Birth of a Nation Revisited. Scope: an Online Journal of Film Studies, dez. 2002. Disponível em: https://www.nottingham.ac.uk/scope/ documents/2002/december-2002/jozajtis.pdf. Acesso em: 10 jul. 2017.

JULLIER, Laurent; MARIE, Michel. Lendo as imagens do cinema. São Paulo: SENAC São Paulo, 2009.

KLOMAN, William. In 2001, will Love be a Seven-Letter Word?. The New York Times, 14 apr. 1968.

$\mathrm{KOH}$, James. Insterstellar and the Liberation of Magic from Genre. Re:Search, v. 3, n. 1, p. 39-55, 2016.

LASSALI, Thais Farias. Mentes elétricas, corpos mecânicos: a noção de humano em 2001: uma odisseia no espaço e Alien, o oitavo passageiro. 2015. Dissertação (Mestrado em Antropologia Social) - Universidade Estadual de Campinas, Instituto de Filosofia e Ciências Humanas, Campinas, SP. Disponível em: <http://www.repositorio.unicamp.br/handle/REPOSIP/279634>. Acesso em: 10 jun. 2018. 
MARTY, Martin. Fundamentals of Fundamentalism. In: KAPLAN, Lawrence. Fundamentalism in Comparative Perspective. Massachusetts: University of Massachusetts Press, 1992.

MAUSS, Marcel. Sociologia e antropologia. São Paulo: CosacNaify, 2003.

OSTENDORF, Berndt. Why is American Popular Culture so Popular? A View from Europe. Amerikastudien/American Studies, v. 46, n. 3, p. 339-366, 2001. PODGAJNA, Patrycja. Between the waste land and no place: Christopher Nolan's futuristic dystopia Interstellar (2014). Studia Humanistyczne Agh, v. 15 , n. 2, p. 51-56, 2016.

RANDAXHE, Fabienne. De 'L'Exception Religieuse' États-Unienne: Retour sur un débat. Archives de Science Sociales des Religions, n. 122, p. 7-25, 2003.

SCHATZ, Thomas. O gênio do sistema: a era dos estúdios em Hollywood. São Paulo: Cia. das Letras, 1991.

SOBCHACK, Vivian. The Limits of Infinity: the American science fiction film. New York: A. S. Barnes and Company, 1980.

SOBCHACK, Vivian. American Science Fiction Film: an Overview. In: SEED, David (ed.). A companion to Science Fiction, Oxford: Blackwell, 2005.

SOBCHACK, Vivian. Time Passages: Space-time is all relative in Christopher Nolan's Interstellar. Film Comment, v. 50, n. 6, p. 20-24, 2014.

VOGLER, Christopher. A jornada do escritor. São Paulo: Aleph, 2015.

WEBER, Max. Rejeiçóes Religiosas do Mundo e Suas Direçóes. In: MILLS, C. W.; GERTH, H. H. Ensaios de Sociologia. Rio de Janeiro: LTC Editora, 1982.

Recebido em: 01/07/2018

Aprovado em: 15/10/2018 